\title{
Approaches to Quality Education in Tertiary Sector: An Empirical Study Using PLS-SEM
}

\author{
Mohammad Ali Ashraf $\mathbb{D}^{1}$ and Hasnan Ahmed $\mathbb{D}^{2}$ \\ ${ }^{1}$ Department of Economics, United International University, Madani Avenue, Gulshan, Dhaka 1212, Bangladesh \\ ${ }^{2}$ School of Business and Economics, United International University, Madani Avenue, Gulshan, Dhaka 1212, Bangladesh \\ Correspondence should be addressed to Mohammad Ali Ashraf; mashraf@eco.uiu.ac.bd
}

Received 25 November 2021; Revised 9 January 2022; Accepted 17 January 2022; Published 22 February 2022

Academic Editor: Xiao-Guang Yue

Copyright (C) 2022 Mohammad Ali Ashraf and Hasnan Ahmed. This is an open access article distributed under the Creative Commons Attribution License, which permits unrestricted use, distribution, and reproduction in any medium, provided the original work is properly cited.

\begin{abstract}
Quality assurance in education has been a critical issue in both private and public higher education in all emerging economies since World War II. Available theories on quality education are numerous, but their strategic models are sparsely sustained. The main objective of this study is, therefore, to articulate and to empirically test a conceptual model to assure and sustain quality in tertiary education grounding on a theory base presented by Chohen and Ball (2006). The model has three parts: independent components, i.e., quality inputs such as quality teachers, quality students, and quality staffs; mediating component, i.e., quality process such as quality programs; and target component, i.e., quality product such as quality education. Data $(n=97$ private universities) were gathered from a report of the university grant commission (UGC), Bangladesh. The data were analysed following PLS-SEM using SmartPLS3 and SPSS software. Findings indicate that all of the predictors appear to be robust in predicting quality education. The results also indicate that the mediating construct has a significant partial mediating role in enhancing quality education in private universities. These outcomes will help academic authorities formulate the right policy option in assuring quality education in higher education institutes in Bangladesh.
\end{abstract}

\section{Introduction}

According to Leo Tolstoy ([1], p. 331), "What is important in knowledge is not quantity, but quality. It is important to know what knowledge is significant, what is less so, and what is trivial" (quoted in [2], p. 2). Nevertheless, quality is often referred to as a relative concept $[3,4]$. Of late, quality evaluation and reassurance processes in providing higher learning have drawn huge responsiveness locally and internationally [5-8]. In reality, the quality aspect of tertiary education is regarded as one of the most important issues in all the emerging economies of the globe [8-10], especially in the country like Bangladesh where more than hundred private universities have been mushroomed during a span of two and half decades [5]. In this condition, the issue of enhancing quality education in the private universities in Bangladesh is, thus, considered to be one of the most gigantic challenges by the academic researchers and policy planners $[5,8]$.

A large number of theories are also available on qualityrelated issues such as TQM [11,12], service quality model or Nordic model [13], SERVQUAL model [14], and cue utilization model [15], to name a few. There have been a large volume of research papers on quality in tertiary education sector as well $[16,17]$. However, most of the theories are focused on different goals in an isolated way [16]. The goal sometimes concentrates on refining course curricula or sometimes on training teaching staff in reformed tutoring methods. A number of such efforts have often been initiated aiming at instructional capacity building in the name of educational reform [6]. Thus, only few of such interventions have noticeable and considerable effects on teaching and quality education in higher education institutes, but they become rarely sustainable over time [10]. 
A rigorous review of research on improving quality education and professional experience suggests somewhat diverse and disheartening findings [16]. One such finding is that educational institutes face different challenges as they are complex organizations and are influenced by various socio-cultural phenomena including families, communities, and professional and controlling authorities [8, 18, 19]. Other studies show that recruitment of quality teachers requires high remuneration or fund which is also difficult for an institute in a developing country context $[20,21]$. Another difficulty is that the emotional and health problems of students sometimes deflect educational issues [21].

The extent of effects of all these measures on quality education is also an important concern [23]. One of the explanations of small effects on quality education is that most higher education institutes are not facilitated with updated teacher training opportunities that would be needed to improve classroom instruction [24]. There are some other explanations too. Some focus on preuniversity education quality [10]. Few concentrate on involving parents to students' academic works [24]. Many intend to improve collegial interactions [25-27]. Most importantly, all these interventions are isolated and different in focus, design, and even approach [16]. Some concentrate mostly on a single factor design: developing curricula or academic programs, training academics in new methods, or adding new technology [28]. Besides, some target reading comprehension [29]; some aim at institutional decision making processes $[30,31]$; and others concentrate on communities and students' welfare conditions [32].

For the field of sustainable practice, these diverse perspectives remind us that in properly-functioning HEIs, effective coordination is necessary for a well-functioning HEI that is rarely noticeable in the present formal systems [7]. Moreover, it often accuses that universities are getting to be more formal and bureaucratized, but there is a need for balancing between quality expectations and a space for open-ended processes [33]. Thus, the three components in our conceptual model also represent distinct underlying logics what ought to be present and matched in the institution. For instance, emphasizing only compliance with standards and merely being focused on accountability and not stressing academic development to ensure quality performance may make institutions stagnated over time [7]. So, quality outcome should focus on the practicalities in improving quality education in increasing complex institutional milieus [33]. Thus, conceptualizing quality input component can both work as a tool for analysing quality enriching processes within institutions and also to cater necessary modifications in formal designs and standards which are already in practice [37].

Based on these diverse experimental backdrops, the present article, thus, explores an integrated and distinct comprehensive conceptual model that represents a novel quality assurance module in higher education institutes incorporating the perspectives of three input components featured by "quality teachers, students, and staff" [38], the process component featured by "quality program" [7], and the product component featured by "quality education or outcome-based quality learning" [36]. This unique new model also has been verified collating secondary data gathered from the Institute for Quality Assurance Cell (IQAC) formed under the auspices of the University Grant Commission (UGC) of Bangladesh.

The design of this study is as follows: first, the underlying theory is concisely reviewed, as are the pertinent literature on quality education in higher education institutes. Next, the conceptual model and hypotheses are provided, followed by a description of the research method and results from the data analysis. An explanation of the meaning of the findings and their implications ends the paper.

\section{Quality Education and Past Literature}

Factually, the term quality has been immensely debated concept in academia since ancient times [37, 38]. As for example, the antiquity of the scepticism and confusion about the nature of quality is brought out by an interesting conversation in one of the celebrated dialogues on "quality medicine" involving Socrates in 410 BC. Socrates speaks with Asculepo, a fresher in the Hippocrates School of Medicine in Athens. Asculepo is conversing with Master Socrates about different lectures at the school on the theme of "quality in healthcare," and in the conversation, on the topic of quality medicine, Socrates asked Asculepo, "What exactly is this thing called quality?" Asculepo replied, "Well, Master Socrates, we did ask one of the professors how he recognized quality so that we might learn to do the same thing. He said that he just recognized good quality whenever he saw it and that it was the opposite of bad quality." Then, Socrates asked again, "Did your professors tell you what were the elements of high quality and how you could measure these elements?" Asculepo answered, "That, Master Socrates, was another confusing part of the lectures." Finally, Socrates asserted, "Yes that certainly sounds confusing" ([39], pp. 855-856).

Etymologically, the term "quality" is evolved from the Latin word "qualitas" that means the degree of excellence of a thing $[6,40]$. Since World War II, there have been myriads of efforts on building instructional capacity to enhance quality education that is rarely sustained over time. In this relation, Cohen and Ball [41] represent a theoretical model (Figure 1) to ensure quality education through building instructional capacity. This capacity building is grounded in interconnections among teachers and students around educational materials rather than separately focusing on them as the principal basis of instruction. On this view, each of the three elements is essential and all three factors are interconnected in the following way as delineated by Cohen and Ball [41].

Teachers' intellectual and personal resources stimulate instructional interactions by determining how teachers comprehend, interpret, react, and answer to materials and students [24]. They must have acquaintance with students' overall knowledge and capability to link and interact with 


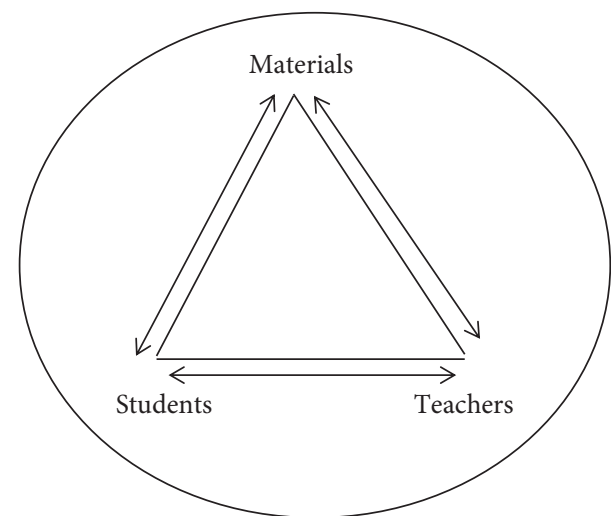

FIGURE 1: Instructional capacity building and quality education (source: [41]).

and knowledge about students and to establish classroom environments $[24,41]$. In parallel to teachers' capacity enhancement, students' prior learning and experience, interests, devotions, and involvements are crucial to their apprehension, interpretation, and response to the materials and teachers. Finally, instructional materials include the texts, tasks, questions, problems, and program contents in which students remain engaged. Instructional materials can mediate students' engagement through technologies of instruction, including print, video, and computer-based multimedia. In this coordinated way, quality education can be assured in a sustainable fashion [41].

Similar to Cohen and Ball [41], Biggs [42] has also presented a model (viz. the $3 \mathrm{P}$ model) to ensure and sustain quality education. According to Biggs [42], the $3 \mathrm{P}$ model is characterized a student's accomplishment in terms of quality education and learning. In regards with the learning program, the design offered to learners seemed to inspire the type of cognitive expertise needed for critical thoughtfulness which requires complementary relations with pragmatic knowledge. As Confucius says, "Seeking knowledge without thinking is labour lost; thinking without seeking knowledge is perilous" (quoted in Cleverley [43]: 6).

Quality education has been a continuing issue of diverged interests, especially in an emerging economic context containing different economic, social, cultural, and institutional environments [8]. In gist, this divergence in its meaning principally subsumes: the multidimensionality of quality [19]; the multiple interpretations of quality viewing from different stakeholders' perspectives [31], comprising providers [19], product users [44], output users, and other concerned sectors [3], and (c) the dynamic change of quality that makes it vulnerable to vary in the milieu of a broader educational, sociocultural, economic, and political landscape [38]. For example, quality was initially recognized as institutional prestige [8], but due to lack of public trust in private higher education sector, institutions diverted their focus toward quality students and their learning $[45,46]$. In recent times, institutions have shifted their attention to innovate pedagogical strategies, virtual lecturing, and digitalization in the present perilous context of the corona pandemic [47-49].

\section{Conceptual Model and Hypotheses}

The underlying conceptual model (see Figure 2) is to examine the quality of education for both public and private higher educational institutes based on the theoretical underpinning presented by Cohen and Ball [41]. This model also addresses the quality areas prescribed by Self-Assessment Manual of University Grant Commission of Bangladesh [50]. As mentioned earlier, the model consists of 5 types of quality constructs: (a) quality faculty, (b) quality student, (c) quality service, (d) quality program, and (e) quality education. For this model, quality faculty, quality student, and quality service are regarded as inputs to influence the quality program and quality education of quality graduates [51]. At the heart of the model remains the quality program of education which is regarded as the process and mediating variable to enhance the quality graduates with quality education as the outcome variable $[3,42]$. There have been different features attached with input such as quality teachers, quality students, and quality staff [51], process such as academic program structure [42], and product such as quality education [3].

As Deming $[11,52]$ specifies production as a process, this concept of production process has been employed in the $5 \mathrm{Q}$ model. In this model, a quality product is the quality graduate who possesses day one skills and experiences necessary for carrying out professional tasks on a daily basis for attaining prespecified organizational goals and objectives.

3.1. Hypotheses Development. As mentioned earlier, the conceptualization of the $5 \mathrm{Q}$ model (Figure 1) is fundamentally based on Cohen and Ball [41] and Biggs [42] who underline their thesis to assure quality in education at large. The quality program lies at the heart of the 5Q model which apply teaching and learning approach in the process for ensuring outcomes-based learning in the academia. This paper has formulated ten hypotheses which are delineated in the next discussion.

3.1.1. Quality Teacher, Quality Student, and Quality Program. In this model, input featured by quality management includes three applied constructs such as quality teaching staff, quality student intake, and quality administrative service. According to the underlying theory [41], quality teacher is an important factor affecting learning outcome and student performance [53] through implementing quality academic program containing effective course curricula [54]. Thus, an urgent issue for both instructors and researchers is how to implement quality teaching program to quality students to achieve quality learning outcomes [55]. Wittek and Habib [17] and Ko and Chung [56] also emphasis on the instructional effects of teachers, including teaching methods, curriculum, and materials of teachers which can have an influence on academic program. So, based on these past studies including theoretical base, it can be postulated that both quality teacher and quality student are positively associated with quality program implementation. Thus, the formal hypotheses are as follows: 


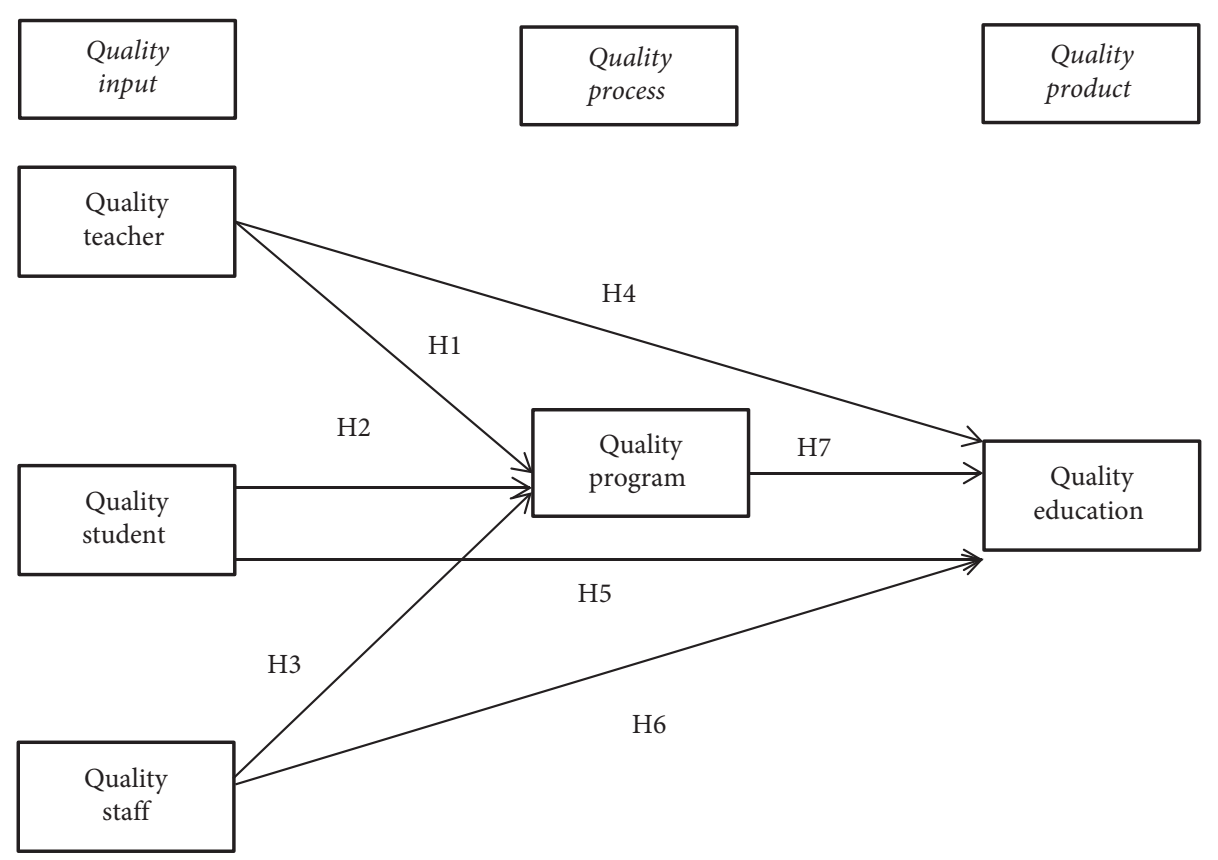

Figure 2: The 5Q model of quality education.

$H_{1}$ : quality teacher has a positive relationship with quality program implementation.

$H_{2}$ : quality student has a positive relationship with quality program implementation.

\subsubsection{Quality Administrative Staff and Quality Program.} Administrative staff used to provide different types of services to stakeholders of an academic institution. These staff also can influence implementation of academic program or program curricula to render quality education to students and other stakeholders [54]. However, there have been few empirical studies on this particular context of academic issue, such as Ahmed and Masud [57]; Ashraf et al. [6]; Ashraf and Osman [58]; and Poole [59]. Ahmed and Masud [57] examine the relation between quality administrative service and quality program implementation and observe a significant positive association between them. Similarly, Ashraf et al. [6]; Osman and Ashraf [58]; and Poole [59] demonstrate that there is a positive significant relationship between quality administrative staff and quality academic program in higher education sector. Thus, it can be hypothesized that

$H_{3:}$ quality staff has a positive relationship with quality academic program implementation.

3.1.3. Quality Teacher and Quality Education. According to Cohen and Ball [41], teachers' quality and students' performance in terms of learning outcomes are closely linked. School systems all over the globe admit that the quality of teaching is the most critical in-school factor impacting on student outcomes [60-62]. Similar finding has been obtained by Johnson [63] who remarks that individuals who care about children's education must agree that availing a good teacher is a key to students' success in life. Of late, scholars have cautiously followed students' achievement over time and confirmed what parents long have known that the quality of their child's teacher can provide quality education and have lifelong consequences [63-66]. In parallel to these studies, empirical evidence suggests that there is a positive association between quality teaching and quality of education $[67,68]$. Thus, it can be hypothesized that

$H_{4:}$ quality teaching has a positive relationship with quality education.

3.1.4. Quality Student and Quality Education. Understanding the quality teaching grounding in quality curricula and program is based on the quality characteristics of learners such as prior knowledge, ability, conception of learning, and language competence [41, 42], for this reason, student in-take ought to be scrutinized based on those quality student characteristics by which students can grasp the mission of quality program and achieve quality education [10]. If students are well-prepared in their preuniversity education, they will be able to digest the quality lectures delivered by the quality teachers focusing quality program in the lectures. However, empirical studies on this particular nexus between those two constructs are rare. Based on the content analysis and few theoretical models, it can be hypothesized that

$H_{5 \text { : }}$ quality student has a positive relationship with quality education.

3.1.5. Quality Staff and Quality Education. In fact, no school can operate effectively without its administrative and operational staff [69]. Be that as it may, quality staff provides quality services to different stakeholders of academic 
institutions such as students, teachers, and parents or guardians of students [69]. Quality staffers functionally include administrative, dormitory, and crucially library departments and others. Library staff very substantially can provide rich collection of teaching and research materials which are essential to produce quality learning outcome. Without adequate supply of books, journals, magazines, and others, quality teaching and quality research are impossible. So, it can be hypothesized that

$H_{6:}$ quality staff has a positive relationship with quality education.

3.1.6. Quality Program and Quality Education. Quality course materials or program is an important factor of overall quality education $[41,42]$. Several studies demonstrate that there are positive relations between academic program or course design and quality learning outcome which is fit for both fast-paced and ever-changing current workplace environment [56, 67]. For this reason, Ritter et al. [67] emphasis on the increased complexity of today's work environment and change in curricula redesign for attaining required quality skills and learning outcome. In a recent study, Osman and Ashraf [4] report that quality program is observed to be positively significant to effect on quality program. All these instances indicate that there is a positive association between quality program and quality education. Thus, it can be hypothesized that

$H_{7:}$ quality program has a positive relationship with quality education.

3.1.7. Mediating Hypotheses. According to Biggs [42], there is a positive relationship between quality teaching context and quality education. Biggs [42] also incorporated quality program as the mediating factor in the links between independent factors and quality learning outcome. Besides, Osman and Ashraf [4] report that quality program has a positive link with quality program. These research works imply that quality program has a mediating effect between quality teacher and quality education. Thus, it can be hypothesized that

$H_{8:}$ quality program has a mediating influence between quality teaching and quality education.

Empirical studies conducted by Osman and Ashraf [4] and Osman et al. [10] reveal that quality student characteristics have a positive significant relation with quality education. Other studies also show that quality program is positively connected with quality education $[4,42]$. Thus, it can be postulated that

$H_{9:}$ quality program has a mediating influence between quality student and quality education.

The people that perform these roles determine how education is delivered and what it needs to develop and progress into the future [63]. Administrative functions also support teaching staff to deliver effective strategy to students and keep educational facilities operating $[10,69]$. While they may not necessarily be perceived as crucial to delivering quality educational services, without operational administrative services, the entire campus could be at risk. Thus, it can be hypothesized that

$H_{10:}$ quality program has a mediating influence between quality staff and quality education.

\section{Methodology}

4.1. Data Sources and Sample. The data for the current study were obtained from the institutional quality assurance cell's (IQAC) report archived in University Grants Commission (UGC) office on the early period of 2020. The report is based on all private and public university's self-assessment results and an external peer review team's (EPRT) evaluation on quality education in tertiary sector of education. As per the UGC guidelines, each school of the private universities prepared a self-assessment (SA) report which was a contextual analysis of different educational issues associated with the quality indicators. The EPRT piloted physical verifications of the SA report while they witnessed the documents and interviewed the stakeholders such as faculty members, students, and administrative and top management authorities and awarded quality scores or points on ten indicators mentioned later in the measurement instrument section. Finally, the committee submitted a report called external peer review report (EPRR), which essentially highlights quality culture and status of the schools with reference to the ten quality education indicators.

To select the sample size, this study employed $\mathrm{G}^{*}$ Power to decide the minimum sample size needed based on statistical power [71]. As the conceptual model has four exogenous variables (predictors of quality education), the analysis selects the effect size as medium (0.35) and power required as 0.95 . The calculation ended up with the required sample size was 96 . Hence, the study decided to gather data which are equal to or slightly larger than the needed number of sample size. Generally, the minimum power needed in social science research is 0.8 as the minimum acceptable power [72, 73]. Besides, it is recommended for PLS-SEM to employ "10 times" rule of thumb as the rule of estimating the minimum needed sample size [74-76]. This guidance recommends that PLS-SEM needs a sample size of 10 times the largest number of paths in the structural model. According to this rule, the current study is required for a minimum sample size of 70 . Thus, it can be safely concluded that a sample of 97 which is considered adequate for this study for ensuring a sufficient statistical power.

4.2. Measurement Instrument. The study considers the quality measures of two schools such as the School of Business and the School Engineering Sciences, which are mostly common in most of the private universities in Bangladesh. Five Likert type quality scales distributed as 1 (unsatisfactory), 2 (poor), 3 (good), 4 (very good), and 5 (excellent) were used to capture the responses for two schools' quality evaluations. These scales were based on ten quality education indicators which are as follows: (a) 
quality governance, (b) quality curriculum design or program, (c) physical facilities, (d) quality student admission, (e) quality teaching, (f) assessment of student performance, (g) student support service, (h) quality staff and services, (i) quality process management for continual improvement, and (j) overall quality education and learning. In the research framework, a total of five variables of those quality indicators were employed such as quality teaching, quality students, quality staff and services, quality curricula and program, and quality education assessment. Among these variables, quality program is selected as the mediating variable in this study. For each of these variables, assessed quality scores for the two schools (School of Business and School of Engineering) were considered for data analysis. At the initial phase, the pretesting was done with a pool of two academicians, three administrative management experts, and five students to clarify and establish the content validity of the constructs. Later on, a pilot study comprising of 30 universities was conducted following Alam et al. [77].

4.3. Model Assessment Using PLS-SEM. The study applied component-based structural equation modelling, namely, PLS-SEM, investigating the predictive capacity of a mediating variable along with other antecedents which demands for using prediction-oriented PLS-SEM [78]. Following Anderson and Gerbing [79], we analysed the data at two stages: firstly, measurement model assessment, and secondly, structural model assessment. PLS-SEM is a statistical technique that permits a simultaneous equation modelling holding a large number of paths in a conceptual model comprising more than one dependent variable. PLS-SEM has been successfully employed in the social science research for a long time [78]. Thus, it is now widely applied in social science and business research $[80,81]$. The conceptual model (presented in Figure 2) was run for attaining factor analysis. The path analysis with item loadings appears in Figure 3. Item loadings were checked to confirm that they are all above 0.6 [78]. The statistical significance of the paths in the model was tested using jackknifing procedure, with a sample size of 1, for 5000 samples. Using one-tailed tests, all seven paths were found statistically significant, four at the $p<0.01$ level, and three at $p<0.05$ level, providing support for $H_{1}, H_{2}, H_{3}, H_{4}, H_{5}$, $H_{6}$, and $H_{7}$. The evaluated model is presented in Figure 4, with critical ratios, $t$-statistics, $R^{2}, f^{2}, Q^{2}$, and VIF listed in Table 1.

\section{Results}

Based on the procedure advanced by Hair et al. [78], the study examined the reliability, convergent validity, and discriminant validity. According to Hair et al. [78], the item loadings, composite reliability (CR), and average variance extracted (AVE) must exceed $0.60,0.70$, and 0.50 to ratify the item reliability, construct reliability, and convergent validity of the constructs, respectively. Table 2 demonstrates that all the factor loadings, CR, and AVE exceeded the suggested threshold levels. Thus, both the indices of reliability and convergent validity in the sample are established.

Moreover, the authors inspected the validity of the constructs in terms of discrimination by applying Fornell and Larcker method. As shown in Table 3, the coefficient of correlation value of any cell is smaller than the square root of AVE values in its corresponding row or column. Hence, the model is said to have discriminant validity [82].

After examining the outer model's reliability and validity, the analysis of the study checked the inner model. In this research, typical 5-step methods were followed as recommended by Hair et al. [78] to run the structural model by PLS-SEM. In the next section, those steps are delineated one by one.

Accordingly, the study first addressed the multicollinearity problem before conducting the structural path analysis. It is recommended that the predictors of the criterion variables must be free from multicollinearity issue. As is evident in Table 1, the calculated VIF-variance inflation factor values are lower than 3.3 [83]; there is no such problem of multicollinearity in this study.

In the second step, the study analysed the prepostulated structural associations by employing the bootstrapping technique with 5000 resamples. As presented in Figure 2 and Table 1, all the hypothesized relationships are observed to be significant. Notably, quality teacher $(\beta=0.496, t=1.906$, $p<0.001)$, quality student $(\beta=0.375, t=5.047, p<0.001)$, quality staff $(\beta=0.230, t=2.339, \quad p<0.001)$, and quality program $(\beta=0.379, t=4.172, p<0.001)$ have positive and the highest impact on quality education as an outcome variable in the research framework supporting $H_{5}, H_{6}$, and $H_{7}$, respectively. Similarly, quality student $(\beta=0.139$, $t=1.524, p<0.05)$ and quality staff $(\beta=0.280, t=1.857$, $p<0.001)$ also have positive and significant influence on quality program which support $H_{1}, H_{2}$, and $H_{3}$, respectively. In the similar fashion, quality student $(\beta=0.117, t=1.431$, $p<0.05)$ has positive and significant influence on quality education and supports $H_{4}$. Besides, quality program has partial mediating effects in the links between quality teacher and quality education $(\beta=0.819, \quad t=14.359, \quad p<0.001$; $\mathrm{VAF}=0.474>0.20)$, quality student and quality education $((\beta=0.628, t=6.306, p<0.001 ; \mathrm{VAF}=0.507>0.20)$. and quality staff and quality student $(\beta=0.739, t=9.817$, $p<0.001 ; \mathrm{VAF}=0.670>0.20)$ partially supporting $H_{8}, H_{9}$, and $H_{10}$. According to Hair et al. [76], partial mediation is demonstrated when variance accounted for (VAF) exceeds the 0.2 threshold level and that full mediation is demonstrated when it exceeds 0.8 .

Third, the explanatory power of the predictors of a dependent variable in terms of coefficient of determination $R^{2}$ was obtained from the path analysis. Figure 2 and Table 1 represent the $R^{2}$ values for quality teacher and quality education as 0.713 and 0.952 , respectively, indicating that those two constructs have strong coefficient of determination and the models have substantially high explanatory power [76].

Fourth, the study calculated the effect size of $f^{2}$ of each of criterion variables flowing [84]. According to the guiding principle, the $f^{2}$ value of $0.02,0.15$, and 0.35 is interpreted as small, medium, and large effect, respectively [85]. Table 1 


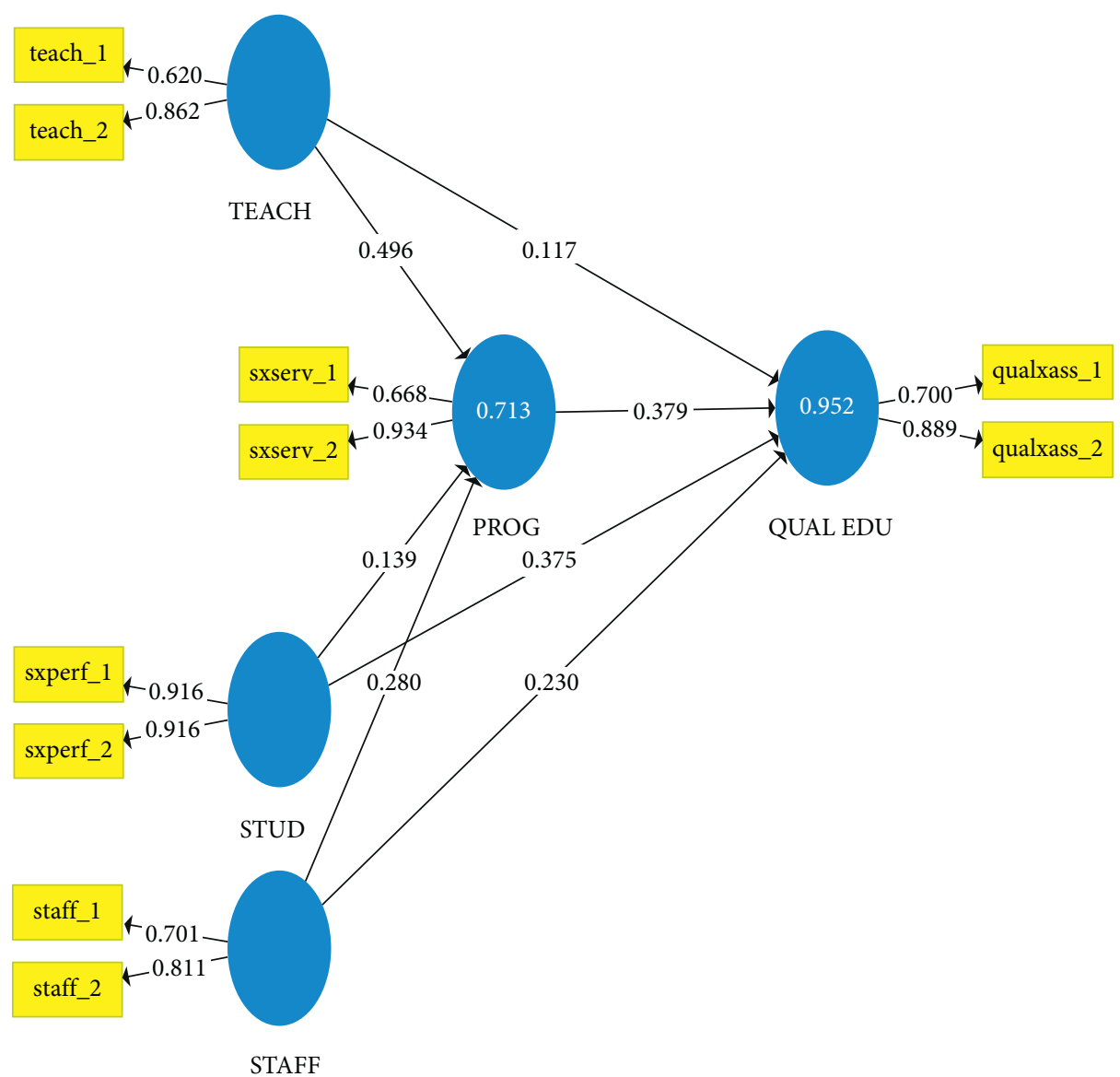

Figure 3: Path analysis results.
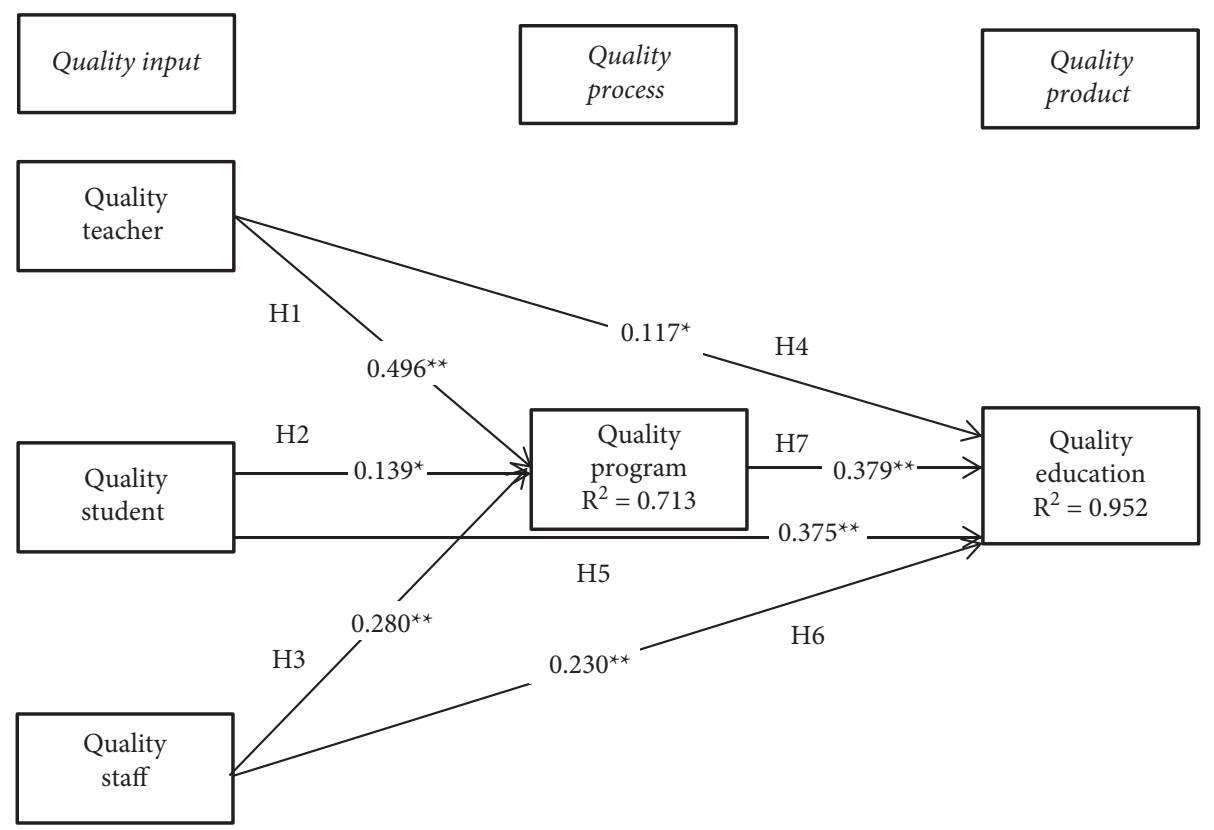

FIGURE 4: Evaluated model. 
TABLE 1: Path analyses evaluation.

\begin{tabular}{|c|c|c|c|c|c|c|c|c|c|}
\hline$H$ & Relationship & Beta & SE & $t$ value & Supported & $R^{2}$ & $f^{2}$ & $Q^{2}$ & VIF \\
\hline \multicolumn{10}{|c|}{ Direct effects } \\
\hline$H_{1}$ & $\mathrm{TEACH} \longrightarrow \mathrm{PROG}$ & 0.496 & 0.260 & $1.906^{* *}$ & Yes & 0.713 & 0.167 & 0.382 & 3.128 \\
\hline $\mathrm{H}_{2}$ & STUD $\longrightarrow$ PROG & 0.139 & 0.151 & $1.524^{*}$ & Yes & & 0.025 & & 2.720 \\
\hline $\mathrm{H}_{3}$ & STAFF $\longrightarrow$ PROG & 0.280 & 0.016 & $1.657^{*}$ & Yes & & 0.098 & & 2.784 \\
\hline$H_{4}$ & $\mathrm{TEACH} \longrightarrow \mathrm{QUAL}$ EDU & 0.117 & 0.013 & $1.431^{*}$ & Yes & 0.952 & 0.048 & & 3.185 \\
\hline$H_{5}$ & STUD $\longrightarrow$ QUAL EDU & 0.375 & 0.074 & $5.047^{* *}$ & Yes & & 1.051 & 0.529 & 2.787 \\
\hline$H_{6}$ & $\mathrm{STAFF} \longrightarrow$ QUAL EDU & 0.230 & 0.099 & $2.339^{* *}$ & Yes & & 0.363 & & 3.150 \\
\hline $\mathrm{H}_{7}$ & $\mathrm{PROG} \longrightarrow$ QUAL EDU & 0.379 & 0.091 & $4.172^{* *}$ & Yes & & 0.861 & & 3.020 \\
\hline \multicolumn{10}{|c|}{ Mediating effects } \\
\hline$H_{8}$ & $\mathrm{TEACH} * * \mathrm{PROG} \longrightarrow \mathrm{QUAL} \mathrm{EDU}$ & 0.819 & 0.057 & $14.359^{* *}$ & Yes & & & & \\
\hline$H_{9}$ & STUD $*$ PROG $\longrightarrow$ QUAL EDU & 0.682 & 0.043 & $6.306^{* *}$ & Yes & & & & \\
\hline$H_{10}$ & STAFF $*$ PROG $\longrightarrow$ QUAL EDU & 0.739 & 0.035 & $9.817^{* *}$ & Yes & & & & \\
\hline
\end{tabular}

${ }^{* *} p<0.01 ;{ }^{*} p<0.05$.

TABLE 2: Measurement model evaluation.

\begin{tabular}{llcr}
\hline Construct & Item & Loadings & CR \\
Quality teacher & TEACH1 & 0.620 & 0.705 \\
Quality student & TEACH2 & 0.862 & 0.563 \\
& SXPERF1 & 0.916 & 0.900 \\
Quality staff & SXPERF2 & 0.916 & 0.838 \\
& SXSERV1 & 0.701 & 0.796 \\
Quality program & SXSERV2 & 0.811 & 0.575 \\
Quality education & PROG1 & 0.668 & 0.609 \\
& PROG2 & 0.934 & 0.778 \\
\hline
\end{tabular}

Note. $\mathrm{CR}=$ composite reliability; $\mathrm{AVE}=$ average variance extracted.

TABLE 3: Discriminant validity.

\begin{tabular}{lcccr}
\hline Construct & 1 & 2 & 3 & 4 \\
\hline Quality teacher (1) & $\mathbf{0 . 7 5 1}$ & & & \\
Quality student (2) & 0.744 & $\mathbf{0 . 9 1 6}$ & $\mathbf{0 . 7 5 8}$ & \\
Quality staff (3) & 0.740 & 0.540 & 0.747 & $\mathbf{0 . 8 1 2}$ \\
Quality program (4) & 0.726 & 0.679 & 0.708 & 0.790 \\
Quality education (5) & 0.735 & 0.784 & $\mathbf{0 . 8 0 0}$ \\
\hline
\end{tabular}

Bold values on diagonal represent the square-roots of AVE values provided in Table 2.

illustrates that quality student, quality staff, and quality program have large effects on quality education variable. However, quality teacher has medium effect on quality program. Furthermore, all other independent variables have small effect on their corresponding dependent variable.

Finally, the study examined the predictive relevancy $\left(Q^{2}\right)$ of the model following Henseler et al. [80]. The model is considered to have predictive relevancy if the $Q^{2}$ value is more than zero [78]. As represented in Table 1 , the $Q^{2}$ values for quality program and quality education are 0.382 and 0.529 , respectively, indicating that the predictive relevancy is medium and high correspondingly.

\section{Discussion}

One of the underlying premises is quality input such as quality teaching staff, quality student, and quality administrative staff can impact on quality program identified as quality process which, in turn, influences quality education identified as outcome variable. It has been observed from the analysis of outputs that quality teaching staff has positive and significant impacts on both quality program and quality education. These findings are supported by several scholars in the similar context of quality assurance in education $[63,86]$. The positive influence of quality student on both quality program and quality education has also appeared significant. Notably, quality student has a robust influence on quality education. Similar observation has been echoed by Morrison and van der Werf [87] who notice that student performance has strong effects on entry and has moderate effects on attrition and completion. These outcomes are compatible with the quality graduates produced by the high ranked academic institutes all over the world [4].

Besides, quality administrative staff has positive and significant effect on quality program and quality education. There is evidence that administrative staff has a collaborative and associative role in facilitating different services to teaching and research activities which are considered to be 
important resources for innovative knowledge creation and further development [87]. This outcome corroborates several earlier studies in the similar field [69]. The assumed positive effect of quality program on quality tertiary education has also appeared highly positively significant. Rich contents of curricula and academic program are empirically proven to be associated with enhancing quality education and this outcome is consistent with the numerous scholarly works [41, 68, 86, 88-95]. Besides, quality program has observed to be mediating in the link between the three quality inputs and quality tertiary education. These types of mediating roles of quality program are evident in several earlier scholarly works in the similar context [42].

6.1. Implications for Research and Practice. First of all, the underlying theory helps construct the current conceptual model. Theoretically, it shows its robustness for aiding to explain and predict quality education in tertiary sector. One of the most important contributing implications for research in the current study is that quality curriculum or quality program is observed to be the strongest factor to influence quality education as well as to perform as a mediating variable. The second most important contributing lesson of this study is that quality student and quality staffers are also found to be robust to impact on quality education. Thirdly, quality teacher demonstrates significant influence on both quality program and quality education. As a general theory, Cohen and Ball [41] suggest that the three quality inputs such as quality teachers, quality students, and quality staff are instrumental to directly determine the quality program which, in turn, highly influences overall quality education. So, this study implies that the underlying theory yields efficient results in terms of predicting and explaining quality indicators of quality education in the tertiary education sector. Thus, as a general theory, these explanations contribute to connect to an overarching theoretical perspective or framework.

From practical perspectives, these results imply that all five quality variables ought to be carefully incorporated in the plan that pursue enhancing quality education outcome. As a matter of fact, in addition to the variables identified in the research framework, there are other factors that can affect quality education such as governance, physical facilities, process management, research, and extension. As more and more empirical works on quality education will emerge, it would be easy to advise policy planners and responsible authorities to formulate right educational materials and maintain proper process management. In this study, the one area of findings that may help academic authorities the most concerns quality processes or programs.

\section{Conclusions}

The main objective of the present article is to examine a research model that articulates a few factors of quality assurance in education. This study concludes that quality assurance in education is a key dimension in the successful accomplishment of any educational institution. Based on the projected research structure, quality education can be enhanced through the employment of quality faculty members, admission of quality entrant students, and provision of quality administrative services to the concerned stakeholders.

This projected research model is a conceptual model which has been quantitatively investigated to check the model's predictability as well as its explicability. The relevance, practicality, and adequacy of the framework ought to be examined as well in further empirical studies. These types of testing of this research model in further empirical procedures would cater helpful information and insights to professionals when utilizing the framework. The present paper does not demonstrate explicit competencies and extensive variables that put effects on graduate record in the job sector. More empirical research works ought to highlight different explicit competencies that affect practical works of the graduates based on different contexts.

\section{Data Availability}

The data used to support the findings of this study will be available on request from the corresponding author.

\section{Conflicts of Interest}

The authors declare that they have no conflicts of interest.

\section{References}

[1] L. Tolstoy, A Calendar of Wisdom: Daily Thoughts to Nourish the Soul, P. Sekirin, Ed., Charles Scribner, New York, NY, USA, 1997.

[2] P.-A. Balland and D. Rigby, "The Geography of complex knowledge," Economic Geography, vol. 93, no. 1, pp. 1-23, 2017.

[3] L. Harvey and D. Green, "Defining quality," Assessment \& Evaluation in Higher Education, vol. 18, no. 1, pp. 9-34, 1993.

[4] A. R. Osman and M. A. Ashraf, "The mediating role of placement in service quality of education: from international students' perspective," Iranian Journal of Management Studies, vol. 12, no. 4, pp. 531-558, 2019.

[5] M. A. Ashraf, "Influences of working condition and faculty retention on quality education in private universities in Bangladesh: an analysis using SEM," International Journal of Educational Management, vol. 33, no. 1, pp. 1-20, 2019.

[6] M. A. Ashraf, A. Z. R. Osman, and S. R. A. Ratan, "Determinants of quality education in private universities from student perspectives," Quality Assurance in Education, vol. 24, no. 1, pp. 123-138, 2016.

[7] M. Elken and B. Stensaker, "Conceptualising 'quality work' in higher education," Quality in Higher Education, vol. 25, no. 1, pp. 1-14, 2018.

[8] S. K. Gill, A. Dhir, G. Singh, and D. Vrontis, "Transformative quality in higher education institutions (HEIs): conceptualisation, scale development and validation," Journal of Business Research, vol. 138, no. 2020, pp. 275-286, 2022.

[9] T. D. Nguyen, "Signal quality and service quality: a study of local and international MBA programs in Vietnam," Quality Assurance in Education, vol. 17, no. 4, pp. 364-376, 2009.

[10] A. R. Osman, A. S. Sohel-Uz-Zaman, M. A. Ashraf, and A. Uddin, "Vindicating service quality of education through 
structural equation modeling (SEM): international students' perspective," International Journal of Higher Education, vol. 9, no. 3, pp. 158-172, 2020.

[11] W. E. Deming, The New Economics, MIT Center for Advanced Educational Services, Cambridge, MA, USA, 1990.

[12] J. C. Flores-Molina, A Total Quality Management Methodology for Universities, Unpublished Doctoral Thesis, Florida International University, Miami, FL, USA, 2011.

[13] C. Grönroos, "A service quality model and its marketing implications," European Journal of Marketing, vol. 18, no. 4, pp. 36-44, 1984.

[14] A. Parasuraman, V. Ziethaml, and L. L. Berry, "SERVQUAL: a multiple- item scale for measuring consumer perceptions of service quality," Journal of Retailing, vol. 62, no. 1, pp. 12-40, 1988.

[15] J. C. Olson and J. Jacoby, "Cue utilization in the quality perception process," in Proceedings of the Third Annual Conference of the Association for Consumer Research, M. Venkaresan, Ed., Association for Consumer Research, Chicago, IL, USA, 1972.

[16] A. C. Rapp and A. Corral-Granados, "Understanding inclusive education-a theoretical contribution from system theory and the constructionist perspective," International Journal of Inclusive Education, pp. 1-17, 2021.

[17] L. Wittek and L. Habib, "Quality teaching and learning as practice within different disciplinary discourses," International Journal of Teaching and Learning in Higher Education, vol. 25, no. 3, pp. 275-287, 2013.

[18] M. Ainscow, R. Slee, and M. Best, "The salamanca statement: 25 Years on," International Journal of Inclusive Education, vol. 23, no. 7-8, pp. 671-676, 2019.

[19] R. Voss, T. Gruber, and I. Szmigin, "Service quality in higher education: the role of student expectations," Journal of Business Research, vol. 60, no. 9, pp. 949-959, 2007.

[20] H. S. Akareem and S. S. Hossain, "Determinants of education quality: what makes students' perception different?" Open Review of Educational Research, vol. 3, no. 1, pp. 52-67, 2016.

[21] S. Waddock and J. M. Lozano, "Developing more holistic management education: lessons learned from two programs," Academy of Management Learning \& Education, vol. 12, no. 2, pp. 265-284, 2013.

[22] World Bank, The Education Crisis: Being in School is Not the Same as Learning, World Bank, Washington, DC, USA, 2019.

[23] L. Harvey, "A history and critique of quality evaluation in the UK," Quality Assurance in Education, vol. 13, no. 4, pp. 263-276, 2005.

[24] I. Naite, "Impact of parental involvement on children's academic performance at crescent international school, Bangkok, Thailand," IOP Conference Series: Earth and Environmental Science, vol. 690, no. 1, Article ID 012064, 2021.

[25] J. Arnold, "A subjective academic narrative reviewing academic collegiality," International Education Research, vol. 2, no. 4, pp. 26-37, 2014.

[26] R. E. Cipriano, Facilitating a Collegial Department in Higher Education: Strategies for Success, Jossey-Bass, San Francisco, CA, USA, 2011.

[27] S. Palaniandy, "Collegiality versus instructional support," Journal of International Society for Teacher Education, vol. 21, no. 2, pp. 50-56, 2017.

[28] J. Berbegal-Mirabent, J. L. Sánchez García, and D. E. RibeiroSoriano, "University-industry partnerships for the provision of R\&D services," Journal of Business Research, vol. 68, no. 7, pp. 1407-1413, 2015.
[29] Texas Educational Agency, "Comprehension instruction," 2002, https://www.netxv.net/pm_attach/67/TRIComprehension_Instr.pdf.

[30] E. M. Pertusa-Ortega, P. Zaragoza-Sáez, and E. ClaverCortés, "Can formalization, complexity, and centralization influence knowledge performance?" Journal of Business Research, vol. 63, no. 3, pp. 310-320, 2010.

[31] P. A. Rauschnabel, N. Krey, B. J. Babin, and B. S. Ivens, "Brand management in higher education: the university brand personality scale," Journal of Business Research, vol. 69, no. 8, pp. 3077-3086, 2016.

[32] C. Ross, J. Bathurst, and A. Jarden, "Well-being and academic success," in Open Learning for an Open World: Reflections on Open and Distance Learning and Teaching at the Open Polytechnic of New Zealand, J. Barrett, Ed., The Open Polytechnic of New Zealand, Lower Hutt, New Zealand, 2012.

[33] B. R. Martin, "What's happening to our universities?" Prometheus, vol. 34, no. 1, pp. 7-24, 2016.

[34] W. Zheng, B. Yang, and G. N. McLean, "Linking organizational culture, structure, strategy, and organizational effectiveness: mediating role of knowledge management," Journal of Business Research, vol. 63, no. 7, pp. 763-771, 2010.

[35] M. Manatos, C. S. Sarrico, and M. J. Rosa, "The integration of quality management in higher education institutions: a systematic literature review," Total Quality Management, vol. 28, no. 1/2, pp. 159-75, 2017.

[36] L. Harvey and B. Stensaker, "Quality culture: understandings, boundaries and linkages," European Journal of Education, vol. 43, no. 4, pp. 427-442, 2008.

[37] G. Doherty, "Quality assurance in education," in Quality Assurance and Management, M. Savsar, Ed., In Tech, Rijeka, Croatia, 2012.

[38] L. Schindler, S. Puls-Elvidge, H. Welzant, and L. Crawford, "Definitions of quality in higher education: a synthesis of the literature," Higher Learning Research Communications, vol. 5, no. 3, pp. 3-13, 2015.

[39] J. S. Alpert, "Socrates on quality," The American Journal of Medicine, vol. 131, no. 8, pp. 855-856, 2018.

[40] Oxford Dictionary, Oxford Dictionary, Oxford University Press, Oxford, UK, 2003.

[41] D. K. Cohen and D. L. Ball, Instruction, Capacity, and Improving Instruction. CPRE Research Report Series RR-43, Graduate School of Education, University of Pennsylvania, Philadelphia, PA, USA, 2006.

[42] J. B. Biggs, "Approaches to learning in secondary and tertiary students in Hong Kong: some comparative studies," Educational Research Journal, vol. 6, no. 1, pp. 27-39, 1991.

[43] J. Cleverley, The Schooling of China, George Allen \& Unwin, Sydney, Australia, 1985.

[44] J. Cullen, J. Joyce, T. Hassall, and M. Broadbent, "Quality in higher education: from monitoring to management," Quality Assurance in Education, vol. 11, no. 1, pp. 5-14, 2003.

[45] A. Amaral and M. J. Rosa, "Recent trends in quality assurance," Quality in Higher Education, vol. 16, no. 1, pp. 59-61, 2010.

[46] T. Ellson, "Assessing contribution of research in business to practice," Journal of Business Research, vol. 62, no. 11, pp. 1160-1164, 2009.

[47] J. Crawford, K. Butler-Henderson, J. Rudolph, and M. Glowatz, "COVID-19: 20 countries' higher education intra-period digital pedagogy responses," Journal of Applied Teaching and Learning, vol. 3, no. 1, pp. 1-20, 2020. 
[48] N. Donthu and A. Gustafsson, "Effects of COVID-19 on business and research," Journal of Business Research, vol. 117, pp. 284-289, 2020.

[49] S. Krishnamurthy, "The future of business education: a commentary in the shadow of the Covid-19 pandemic," Journal of Business Research, vol. 117, pp. 1-5, 2020.

[50] UGC, Annual Report, University Grand Commission, Dhaka, Bangladesh, 2018.

[51] K. C. Barker, Canadian Recommended E-Learning Guidelines, Future Ed for Canadian Association for Community Education and Office of Learning Technologies, HRDC, Vancouver, BC, USA, 2002.

[52] W. E. Deming, Quality Management, MIT Press, Cambridge, MA, USA, 1982.

[53] N. Snehi, "Improving teaching -learning process in schools: a challenge for the 21 st century," Learning Community, vol. 2, no. 1, pp. 1-12, 2011.

[54] P. Stabback, "What makes a quality curriculum? In-progress reflection no. 2 on current and critical issues in curriculum and learning series," UNESCO International Bureau of Education, UNESCO, Paris, France, 2016.

[55] N. Becket and M. Brookes, "Quality management practice in higher education - what quality are we actually enhancing?" The Journal of Hospitality, Leisure, Sport and Tourism, vol. 7, no. 1, pp. 40-54, 2008.

[56] W. Ko and F. Chung, "Learning Satisfaction for Culinary Students: the effect of teaching quality and professional experience," International Journal of Vocational and Technical Education, vol. 7, no. 1, pp. 1-13, 2015.

[57] S. Ahmed and M. M. Masud, "Measuring service quality of a higher educational institute towards student satisfaction," American Journal of Educational Research, vol. 2, no. 7, pp. 497-455, 2014.

[58] A. R. Osman and M. A. Ashraf, "A quality probe of the private MBA program: evidence from Bangladesh," Journal of Education and Practice, vol. 5, no. 23, pp. 58-66, 2014.

[59] B. Poole, "Quality, semantics and the two cultures," Quality Assurance in Education, vol. 18, no. 1, pp. 6-18, 2010.

[60] J. Gore, A. Lloyd, M. Smith, J. Bowe, H. Ellis, and D. Lubans, "Effects of professional development on the quality of teaching: results from a randomised controlled trial of quality teaching rounds," Teaching and Teacher Education, vol. 68, pp. 99-113, 2017.

[61] J. Hattie, Visible Learning: A Synthesis over 800 Meta-Analyses Relating to Achievement, Taylor \& Francis, Hoboken, NJ, USA, 2008.

[62] H. Timpereley and A. Alton-Lee, "Reframing teacher professional learning: an alternative policy approach to strengthening valued outcomes for diverse learners," Review of Research in Education, vol. 32, pp. 328-369, 2008.

[63] S. M. Johnson, The Workplace Matters: Teacher Quality, Retention, and Effectiveness, National Education Association, Washington, DC, USA, 2006.

[64] D. F. McCaffrey, J. R. Lockwood, D. M. Koretz, and L. S. Hamilton, Evaluating Value-Added Models for Teacher Accountability, Rand Education, New York, NY, USA, 2003.

[65] S. G. Rivkin, E. A. Hanushek, and J. F. Kain, Teachers, Schools, and Academic Achievement, University of TexasDallas Texas Schools Project, Dallas, TX, USA, 2002.

[66] B. Rowan, R. Correnti, and R. J. Miller, "What large-scale, survey research tells us about teacher effects on student achievement: insights from the prospects study of elementary schools," Teachers College Record, vol. 104, no. 8, pp. 1525-1567, 2002.
[67] J. E. Rockoff, "The impact of individual teachers on student achievement: evidence from panel data," The American Economic Review, vol. 94, no. 2, pp. 247-252, 2004.

[68] UNESCO, EFA Global Monitoring Report 2005: Education for All - the Quality Imperative, UNESCO Publishing, Paris, France, 2004.

[69] J. N. L. Lamptey, I. M. Umude, and E. Atteh, "The role of administrative staff in student relationship management (SRM); A tool for quality teacher education," Asian Journal of Advanced Research and Reports, vol. 13, no. 2, pp. 5-15, 2020.

[70] J. K. Ritter, M. Lunenberg, K. Pithouse-Morgan, A. P. Samaras, and E. Vanassche, Eds., Teaching, Learning and Enacting Self-Study Methodology: Unravelling a Complex Interplay, Springer, New York, NY, USA, 2018.

[71] F. Faul, E. Erdfelder, A. Buchner, and A.-G. Lang, "Statistical power analyses using $G^{*}$ power 3.1: tests for correlation and regression analyses," Behavior Research Methods, vol. 41, no. 4, pp. 1149-1160, 2009.

[72] J. F. Hair, G. T. M. Hult, C. M. Ringle, and M. Sarstedt, $A$ Primer on Partial Least Squares Structural Equation Modeling (PLS-SEM), Sage, Thousand Oaks, CA, USA, 2013.

[73] D. Gefen, E. Rigdon, and D. Straub, "An update and extension to SEM guidelines administrative and social science research," MIS Quarterly, vol. 35, no. 2, pp. 3-24, 2011.

[74] D. Gefen, D. W. Straub, and M.-C. Boudreau, "Structural equation modeling and regression: guidelines for research practice," Communications of the Association for Information Systems, vol. 4, no. 7, pp. 1-70, 2000.

[75] W. W. Chin, "How to write up and report PLS analyses," in Hand Book of Partial Least Squares, pp. 655-690, Springer, New York, NY, USA, 2010.

[76] J. F. Hair, C. M. Ringle, and M. Sarstedt, "PLS-SEM: indeed a silver bullet," Journal of Marketing Theory and Practice, vol. 19, no. 2, pp. 139-152, 2011.

[77] M. Z. Alam, W. Hu, A. Kaium, R. Hoque, and M. M. D. Alam, Understanding the Determinants of $m$ Health Apps Adoption in Bangladesh: A SEM-Neural Network Approach. Technology in Society, vol. 61, Article ID 101255, 2020.

[78] J. F. Hair, G. T. M. Hult, C. M. Ringle, and M. Sarstedt, $A$ Primer on Partial Last Squares Structural Equation Modeling, Sage, Thousand Oaks, CA, USA, 2017.

[79] J. C. Anderson and D. W. Gerbing, "Structural equation modeling in practice: a review and recommended two-step approach," Psychological Bulletin, vol. 103, no. 3, pp. 411-423, 1988.

[80] J. Henseler, C. M. Ringle, and R. R. Sinkovics, "The use of partial least squares path modeling in international marketing," Advances in International Marketing, vol. 20, pp. 277-319, 2009.

[81] C. M. Ringle and M. Sarstedt, "Gain more insight from your PLS-SEM results," Industrial Management \& Data Systems, vol. 116, no. 9, pp. 1865-1886, 2016.

[82] C. Fornell and D. F. Larcker, "Evaluating structural equation models with unobservable variables and measurement error," Journal of Marketing Research, vol. 18, no. 1, pp. 39-50, 1981.

[83] N. Kock, G. Lynn, and G. Lynn, "Lateral collinearity and misleading results in variance-based SEM: an illustration and recommendations," Journal of the Association for Information Systems, vol. 13, no. 7, pp. 546-580, 2012.

[84] J. F. Hair, M. Sarstedt, and C. M. Ringle, "Rethinking some of the rethinking of partial least squares," European Journal of Marketing, vol. 53, no. 4, pp. 566-584, 2019. 
[85] J. Cohen, Statistical Power Analysis for the Behavioural Sciences, Routledge, Hilldale, NJ, USA, 2nd edition, 1988.

[86] B. Boyle, W. David, and B. Trudy, "A longitudinal study of teacher change: what makes professional development effective?" Working Paper No. 1, University of Manchester, Institute for Political and Economic Governance, Manchester, UK, 2003.

[87] K. Morrison and G. van der Werf, "The importance of the "so what" factor in educational research," Educational Research and Evaluation, vol. 25, no. 7-8, pp. 333-335, 2019.

[88] ADEA, The Challenge of Learning: Improving the Quality of Basic Education in Sub-Saharan Africa, Association for the Development of Education in Africa (ADEA), Paris, France, 2005.

[89] S. E. Anderson, Ed., Improving Schools through Teacher Development: Case Studies of the Aga Khan Foundation Projects in East Africa, Swets and Zeitlinger, Lisse, The Netherlands, 2002.

[90] D. K. Cohen and H. C. Hill, Instructional Policy and Classroom Performance: The Mathematics Reform in California, Consortium for Policy Research in Education, University of Pennsylvania, Philadelphia, PA, USA, 1998.

[91] K. M. Lewin and J. S. Stuart, Research Teacher Education: New Perspectives on Practice, Performance and Policy, MUSTER Synthesis Report, University of Sussex and Department for International Development (DFID) Educational Papers, Sussex, UK, 2003.

[92] UNICEF, Defining Quality in Education. Working Paper Series, UNICEF, New York, NY, USA, 2000.

[93] UNESCO, Teachers and Educational Quality: Monitoring Global Needs for 2015, UNESCO Institute for Statistics, Montreal, Canada, 2006.

[94] USAID/EQUIP1, Developing a Positive Environment for Teacher Quality, EQUIP1 Program, Washington, DC, USA, 2004.

[95] A. Verspoor, Schools at the Center of Quality. ADEA Newsletter, Special Issue-Biennale 2006, 2006.

[96] M. A. Ashraf, Macroeconomic Essentials for Business, Lambert Academic Publishers, New York, NY, USA, 2012.

[97] J. Biggs, "The reflective institution: assuring and enhancing the quality of teaching and learning," Higher Education, vol. 41, no. 3, pp. 221-238, 2001.

[98] C. L. Bobby, "The Abcs of building quality cultures for education in a Global world," in Proceedings of the International Conference on Quality Assurance, Bangkok, Thailand, 2014.

[99] D. N. Diwedi, Microeconomics: Theory and Applications, Pearson Education, Delhi, India, 2003.

[100] D. L. Goetsch and S. B. Davis, Quality Management for Organizational Excellence: Introduction to Total Quality, Pearson, Hoboken, NJ, USA, 2010.

[101] L. Harvey and J. Newton, "Transforming quality evaluation: moving on," Higher Education Dynamics, vol. 20, pp. 225245, 2007.

[102] V. Hulpiau and K. Waeytens, "Improving the quality of education: what makes it actually work? a case study," in Realising Qualitative Research into Higher Education, C. Prichard and P. Trowler, Eds., Ashgate Publishing, Aldershot, UK, 2003.

[103] G. Knowles, Quality Management, https://Bookboon.Com, 2011.

[104] F. Choon Boey Lim, "Understanding quality assurance: a cross country case study," Quality Assurance in Education, vol. 16, no. 2, pp. 126-140, 2008.
[105] J. Mikkonen, A. Heikkilä, M. Ruohoniemi, and S. Lindblom-Ylänne, “"I study because I'm interested”: university students' explanations for their disciplinary choices," Scandinavian Journal of Educational Research, vol. 53, no. 3, pp. 229-244, 2009.

[106] M. Sarstedt and J. F. Hair, C. M. Ringle, K. O. Thiele, and S. P. Gudergan, Estimation issues with PLS and CBSEM: where the bias lies!" Journal of Business Research, vol. 69, no. 10, pp. 3998-4010, 2016.

[107] UNESCO, EFA Global Monitoring Report, UNESCO Publishing, Paris, France, 2005.

[108] J. Williams, "Editorial," Quality in Higher Education, vol. 25, no. 1, pp. 1-3, 2019. 